\title{
Description and Analysis of Psychological Intervention with Dancers by the Software IRAMUTEQ
}

\author{
Andressa Melina Becker da Silva ${ }^{1}$ \\ Sônia Regina Fiorim Enumo \\ Programa de Pós-Graduação em Psicologia, Pontifícia Universidade Católica de Campinas, \\ Campinas, SP, Brazil
}

\begin{abstract}
Dancers live daily with pain, but often they do not know how to deal adequately with it. Based on this concern, we developed a psychological intervention for dancers to cope with pain, applied to 14 Jazz dancers, aged between 12 to 17 years old $(M=14.63 ; S D=1.42)$, who have been competing internationally. This study presents the use of a software for analysis of the verbal reports of dancers and the mediator presented along the psychological intervention. Using the IRAMUTEQ software, we did the held monothematic and thematic analysis on three textual corpus by Hierarchic Analysis Descendant and Similarity Analysis. In the first corpus (mediator reports), were resulted in 5 classes Sensory Process, Pain Register, Intervention Process, Techniques for Stress Management, Coping and Post-Coping. In the second corpus (dancer reports), 5 classes - Challenges in the Pain Game, Dance Risks, Pain Dilemmas, Imagery Training and Relaxing, and Adjustment to the Options Available in the Social Environment. In the third corpus (dancers and mediator reports), 4 classes - Imagination Process, Process of Coping with Pain, Techniques for Stress Management, Process of Evaluation and Intervention. The software showed useful and effective for psychological intervention content analysis.
\end{abstract}

Keywords: Psychological intervention, dance, adolescents, research methods, sports psychology.

\section{Descrição e Análise de uma Intervenção Psicológica com Bailarinos pelo Software IRAMUTEQ}

\section{Resumo}

Bailarinos convivem diariamente com a dor, muitas vezes não sabendo como enfrentá-la adequadamente, o que pode comprometer o desempenho físico e sua qualidade de vida. Baseado nisso, foi desenvolvido um programa de intervenção psicológica no coping da dor para bailarinos, com a duração de oito sessões de aproximadamente 45 minutos, aplicado em 14 bailarinas de Jazz, com idade entre 12 e 17 anos $(M=$ $14,63 ; D P=1,42)$, que competem em nível internacional. Assim, objetivou-se neste estudo apresentar a utilização de um software para avaliação do conteúdo apresentado por bailarinos e mediadora em intervenção psicológica. Através do software IRAMUTEQ, realizou-se análises monotemáticas e temáticas em três corpus textuais. Foram feitas a Análise Hierárquica Descendente e Análise de Similitude. Para o primeiro corpus (relatos da mediadora), foram analisados 417 segmentos de texto (ST), retendo $77,70 \%$ desse total, formando 5 classes - Processo sensorial, Registro da dor, Processo de intervenção, Técni-

Mailing address: Avenida das Pitangueiras, 220, Condomínio Margaridas, Bloco E, Apto. 128, Campinas, SP, Brazil. Phone: (15) 99801-1507. E-mail: andressa_becker@hotmail.com

Financing: Coordenação de Aperfeiçoamento de Pessoal de Nível Superior (CAPES); Conselho Nacional de Desenvolvimento Científico e Tecnológico (CNPQ). 
cas para controle do estresse, Coping e pós-coping. No segundo corpus (relatos das bailarinas), foram analisados $250 \mathrm{ST}$, retendo-se $73,20 \%$ desse total, formando 5 classes - Desafios no contexto do jogo da dor, Riscos da dança, Dilemas da dor, Treino de imaginação e relaxamento, Ajustamento às opções disponíveis no meio social. Para o terceiro corpus (relatos das bailarinas e da mediadora), foram analisados 667 ST, retendo-se $83,96 \%$ desse total, formando 4 classes - Processos de imaginação, Processo de enfrentamento da dor, Técnicas para controle do estresse, Processo de avaliação e intervenção. O software mostrou-se útil e eficaz para análise de conteúdo da intervenção psicológica.

Palavras-chave: Intervenção psicológica, dança, adolescentes, métodos de pesquisa, psicologia do esporte.

\section{Descripción y Análisis de Intervención Psicológica con Bailarines por Software IRAMUTEQ}

\section{Resumen}

Bailarines viven diariamente con el dolor, a menudo no saber cómo lidiar con ella correctamente, lo que puede poner en peligro el rendimiento físico y la calidad de vida. Con base en esto, se desarrolló un programa de intervención psicológica en el dolor para los bailarines, con una duración de ocho sesiones de unos 45 minutos, con 14 bailarines de Jazz, con edades comprendidas entre los 12 a 17 años $(M=$ 14.63; $D E=1.42$ ), que compiten a nivel internacional. El objetivo de este estudio es presentar el uso de un software para la evaluación del contenido revelado por bailarines y mediador en la intervención psicológica. A través del software IRAMUTEQ, se hizo análisis monotemático y temático sobre tres corpus textuales. Se les hizo análisis de clasificación jerárquico descendente y análisis de similitud. Para el primer corpus (relatos del mediador), se analizaron 417 segmentos de texto (ST), con la retención de $77,70 \%$, y la formación de las clases 5 - Proceso sensorial, Registro de dolor, Proceso de intervención, Técnicas para el manejo del estrés, Afrontamiento y post-afrontamiento. En el segundo corpus (relatos de los bailarines) se analizaron $250 \mathrm{ST}$, retuvieran $73,20 \%$ del total, formando cinco clases - Desafíos en el contexto del juego del dolor, Riesgos de la danza, Dilemas del dolor, Entrenamiento de la imaginación y la relajación, Adaptación a las opciones disponibles en el entorno social. Por tercer corpus (relatos de los bailarines y el mediador) se analizaron $667 \mathrm{ST}$, sosteniendo 83,96\% del total, por lo que 4 clases - Procesos de imaginación, Proceso de afrontamiento del dolor, Técnicas para el manejo del estrés, Proceso de evaluación e intervención. El software demostró ser útil y eficaz para el análisis de contenido de la intervención psicológica.

Palabras clave: Intervención psicológica, danza, adolescentes, métodos de investigación, psicología del deporte.

The psychological intervention is one of psychologist professional tasks, aiming to change behaviors, thoughts and emotions to promote better health and quality of life (Chaves \& Vázquez, 2015; Lipp, 2012; Wright, Sudak, Turkington, \& Thase, 2012). The psychological intervention must be design according to the demand observed from the use of psychological assessment, as well as from the theoretical approach of the mediator. Furthermore, it is possible to apply psychological interventions on dif- ferent contexts as hospitals (Alcântara, Shioga, Lima, Lage, \& Maia, 2013; Motta \& Enumo, 2010; Pfeifer \& Ruschel, 2013), schools (Lopes \& Almeida, 2015; Souza et al., 2014), companies (Leandro-França, Murta, \& Villa, 2014; Lino \& Ziliotto, 2013), as well as on sporting and physical activities (Godtsfriedt, Andrade, \& Vasconcellos, 2014; Heaney, Walker, Green, \& Rostron, 2015; Larsen \& Henriksen, 2015; Markland, Hall, Duncan, \& Simatovic, 2015; Weinberg \& Gould, 2014). 
Interventions in Psychology of Sport and Physical Activity are relatively recent, and has been gradually highlighted as result of great sports events, as the Soccer World Cup and the Olympic Games in Brazil (Vieira, Vieira, \& Nascimento, 2013). In their professional practice, Sports and Physical Activity Psychologists have, among other activities, the role of assessing the individual and group psychological phenomena, which affect the sport performance, health, and quality of life of the participants, as their personality and temperament. They also have to pay attention to the psychological demands for carrying out given moves, considering the training phase (Andersen, 2011; Weinberg \& Gould, 2014). After this evaluation, it would be possible to choose the more adequate intervention.

Despite the fact that dance is not a sport discipline, it has aspects in common with sports, for example, an intense training load and the competitions (Guarino, 2015). Thus, dance groups should have a Psychologist qualified in physical activity in their staff, in order to assure the integrity of the dancers.

After the assessment, the sports and physical activity psychologist will choose the best intervention method for the ballet-dancers considering the intervention approach. Assessment instruments may be applied prior to and after the intervention, and, in case of expressive differences in the results, these may be considered psychological change indicators (Karademas, Benyamini, \& Johnston, 2016).

Pain is a possible psychological construct to study in dance because the ballet-dancers live daily with pain symptoms due to their intense training load, with short recovery time (Singh, 2011). Knowing how to cope with this stressor - pain - is a key point, so that the dancers are able to decrease the perception, intensity and frequency of their pain, as well as to present better physical/technical performance with quality of life (Encarnación, Meyers, Ryan, \& Pease, 2000).

Those matters led us to propose an intervention program in coping with pain to teenager ballet-dancers, whose data will be described in this article. We adopted a developmental approach of the coping, proposed by the Motivational Theory of Coping [MTC] as self-regulation process under stressful condition, in which the ways of coping would be refined and differentiated along the lifetime (Ramos, Enumo, \& Paula, 2015; Skinner, Edge, Altman, \& Sherwood, 2003; Skinner \& Wellborn, 1994). The coping is a construct that describes how people regulate their own behavior, emotions and motivational orientation under stressful conditions. That process concerns individual efforts to keep, restore and repair three basic psychological needs, Relatedness, Autonomy and Competence.

The MTC proposes an analysis of the coping based on hierarchical structure, in which there are "coping instances" or coping behaviors (lower categories) that are categorized in "coping strategies" according to their functionality. Those, therefore, also have similar functions and may be grouped in "coping families" (higher categories). When the stressor is appraisal as a challenge to the self or to the context, there are six adaptive coping families: Self-reliance and Support Seeking (related to need of Relatedness), Problem-Solving and Information Seeking (need of Competence), Accommodation and Negotiation (Autonomy need). If the stressor is appraisal as threat to the self or to the context, one of these six maladaptive families may occur: Delegation and Isolation (need of Relatedness), Helplessness and Escape (need of Competence), Submission and Opposition (need of Autonomy; Skinner et al., 2003).

For this intervention program, the following question has been done: "How to describe and analyze the interaction that occurred during an intervention in coping with pain for teenager dancers?" Analyzing the verbal content produced by the participants was important, as well as the psychologist's verbal reports during the mediation. That would be a way of apprehend the intervention process, in an attempt to identify explainable variables for the changes associated to the intervening process. Methodologically, this question has been rarely discussed, with few validated and specialized instruments applied to physical activities studies. Thereby, this study describes the use of software to assess the ver- 
bal reports of the dancers and the mediator in a psychological intervention in coping with pain.

\section{Method}

\section{Participants and Data Source}

The data were collected during an intervention program in coping with pain, consisting of eight sessions mediated by the first author that has degree in Physical Education and Psychology, and technical training in Classical Ballet and Tap Dance, having worked as dancer, including Jazz, for 23 years, and she was a dance teacher for eight years.

The "Programa de Intervenção no Enfrentamento da Dor em Bailarinos" - PIEDORBailarinos (Intervention Program in Coping with Pain for Dancers) is based on proposals from Caudill (1998), Gould, Damarjian and Greenleaf (2011) and from Stefanello (2007), for intervention in athletes and people with chronic pain. This program was based on the first author's experience, who realized the lack of psychological interventions to dancers, and it was supported by previous psychological assessment results in that population, displaying pain worsening and the presence of maladaptive coping strategies. Therefore, based on intervention already used with athletes, we developed a method to apply to ballet dancers, at their own rehearsal site, which could be apply by psychologists. The intervention program occurred in eight sessions, each one lasting 45 minutes, once a week. As the dancers' and athletes' routine consists of a great amount of activities, and because the trainers and teachers limit interruptions and interventions in the groups, a brief intervening program was considered more adequate. The sessions occurred along two months, between August to October, 2014, after competitive period. The general aim of the program was to develop long-term adaptive coping with pain strategies by imagery techniques. Some activities were performed, such as imagining pain situation when dancing in which the dancers would imagine a format to their pain, and then would change it mentally, showing that there would be an affective and emotional control upon it, together with cognitive restructuring and relaxation.

In the sessions, some instruments and materials were used, such as: (a) psycho-educational booklets; (b) Subjective Questionnaire to Assess the Imaginative Capacity (Gould, Damarjian, \& Greenleaf, 2011); (c) Questionnaire for Imagination in Dance (Martens, 1987; Vealey, 1991; freely adapted) with a version for dancers considering the specific terms, for instance, the third item - "Dancing at a Festival" as a substitute for "Playing in a competition" in the athletes' version; (d) Pain Diary and Medication Diary - with questions about intensity, site and frequency of the pain, medication usage and coping strategies, if there is a disease that may worsen or justify the pain, and the type and duration of the physical activity of the day; (e) Pain Game - a psychoeducational resource to promote coping strategies and the recognition of the maladaptive and adaptive coping strategies; (f) User Satisfaction Questionnaire (adapted from Ramos, 2012) with five closed questions and two discursive ones. In pre-test and post-test stages, a set of psychological assessment was also applied for these variables - stress and stressor (subjective and objective measurements, as the ones related to the capillary and salivary cortisol and blood lactic acid), anxiety, physical exercise addiction, selfefficacy, coping with dance, coping with pain, and quality of life. These data about the effects of the intervention will not discuss in this article.

Fourteen Jazz dancers participated in this study, they were aged between 12 and 17 ( $M=$ 14.63; $S D=1.42$ ), and competed at national and international levels. They were selected for presenting high competitive level, and award-winning in several national and international festivals within their modalities and age. The dancers practice 4 hours and 30 minutes a week and another two hours more on Saturdays, in addiction to extra classes, as classical and contemporary ballet, Jazz and Hip Hop. They have been dancing for seven years and have been competing for four years in average. These dancers attended a Dance School in Curitiba, Paraná, Brazil, representing a convenience sample. All of them reported feeling pain. 


\section{Ethical Issues}

All the ethical aspects were act according to Resolution 466/2012 of the National Health Council, Brazil. The Ethical Commitee on Human Research approved this research (Process \#783.537; CAEE \#23756113.3.0000.5481). The dancers only participated after their parents signed the Informed Consent Form, and after the dancers themselves signed the Authorization Form, showing interest in participate in the research.

\section{Procedure and Data Analysis}

Initially, we transcribed each intervention session, and separated the verbal reports of the dancers (group) and the mediator (sport psychologist). The software analysis is qualitative, considering that it analyzes the words of the speech, as well as quantitative because it calculates the frequency and Chi-square test. Moreover, note that a substantial volume of text is required for the analysis to be more precise. Because of this, it was not possible to separate individually the verbal reports for each dancer, taking into account the some speaks more than others do, thus we opted for categorizing their reports as a group.

Subsequently, we organized the textual material of the interviews in three separate corpus. According to Camargo and Justo (2015), there are two ways to prepare the corpus content: the monothematic and the thematic. They are distinguished by the possibility of the second allows more than one theme in the same analysis. Therefore, an analysis of the dancers' verbal reports was carried out, then another one with the mediator, and finally a corpus with two themes (dancers and mediator), in two distinct subthemes. This division was did in order to have a better comprehension of the relations between the verbal reports of dancers and mediator.

The IRAMUTEQ software processed the textual content of these three corpus by the Descending Hierarchical Classification Analysis (DHC) and Similarity Analysis (Camargo \& Justo, 2013, 2015; Ratinaud \& Marchand, 2012). According to Camargo and Justo (2015), IRAMUTEQ allows us to make different forms of statistical analysis about textual corpus and about tables of individuals, by words. Therefore, the software adds to humans and social science studies, which make use of the symbolic content as an important source of research data. Moreover, the socio-demographic matters were descriptively analyzed by the software SPSS (Statistical Package for the Social Science), version 20.0.

\section{Results}

The first corpus analyzed by the IRAMUTEQ contained the verbal reports from the mediator, in a monothematic analysis. The DHC analyzed 417 texts segmentation (TS) and retained $77.70 \%$ out of the total, organized in five classes. Firstly, the software split the corpus in two subcorpora:

1. Sensory Processing - composed by Class 1 related to the Sensory Processing of Imagination;

2. Stress-Coping process and its management - formed by the Class 2, 3, 4, and 5, related to the stress control techniques, intervention process, pain, coping and postcoping record. O software also split this subcorpus again, opposing Class 5 to Class 2, 3 and 4. Finally, it was did a final split, in which Class 4 was opposed to Class 2 and 3 (Figure 1).

Class 1 named "Sensory processing of imagination" was equivalent to $20.70 \%$ of the TS. The main elements (words) related to this class were: show, theater, stage, step, record, feeling, colorful, white, black, sound, smell, emotion, sensation, taste, image, body, among others (Figure 1). This Class 1 content deals mainly with the sensory conditions necessary for the process of imagination to occur. The following extracts illustrate this context:

"The sound in the theater rang for the first time, 10 minutes left. How is your body now? What sensations come?" (Session 7-S7).

"Perceive yourself doing each movement from this choreography. What sounds does it have? How is your body now? Is everything colorful or black and white?" (S3). 


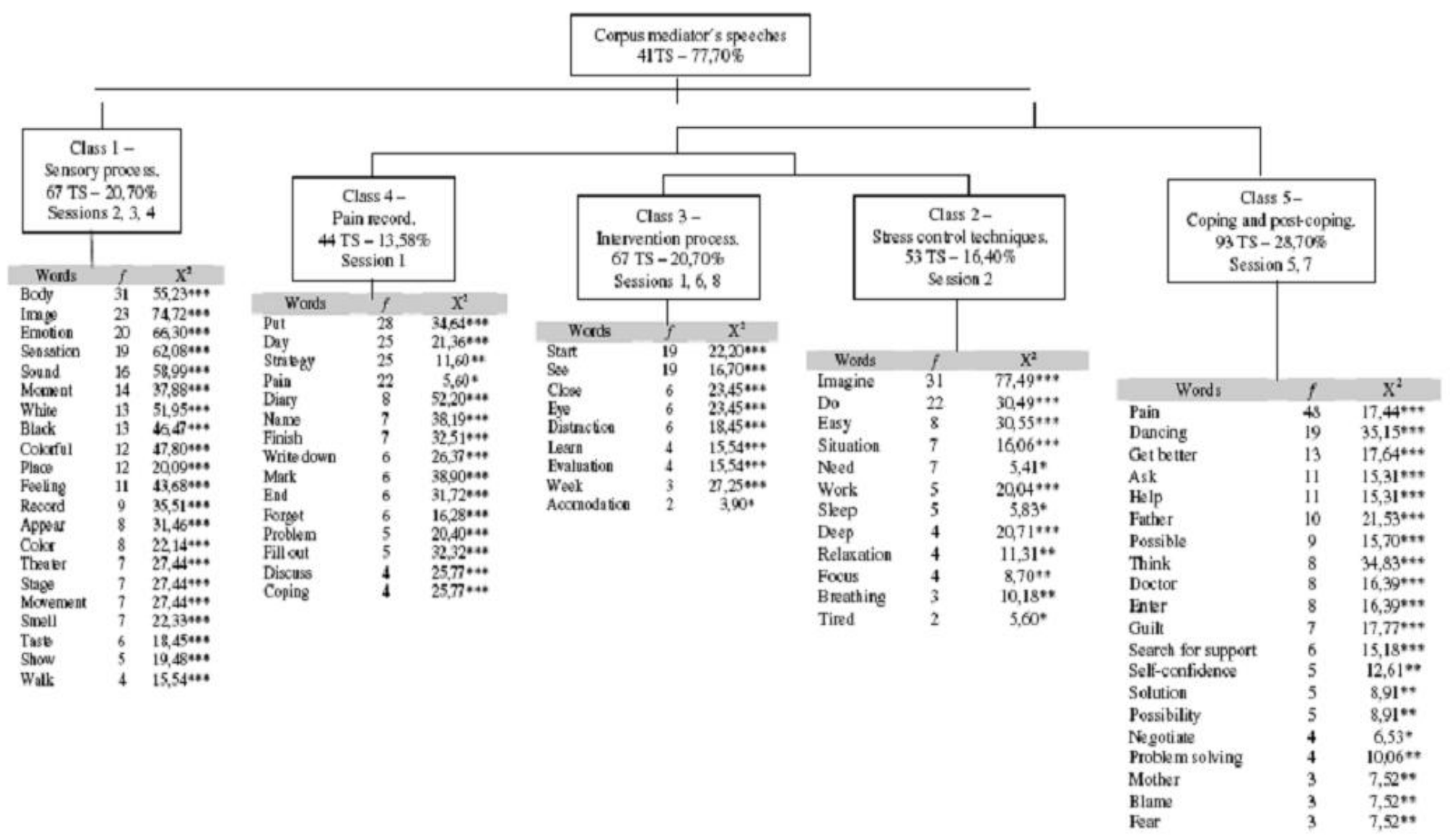

Figura 1. Mediator's report analysis during the intervention program in coping with pain in dancers by Descending Hierarchical Classification.

Note: ${ }^{*} \mathrm{p}<00,5 ;{ }^{*} \mathrm{p}<00,1 ; * * \mathrm{p}<0,0001$, Qui-Squared test, IRAMUTEQ software.

Class 5 entitled "Coping and post-coping" was equivalent to $28.70 \%$ of TS. These are its main words: dance, negotiate, possible, think, ask, help, enhance, pain, mother, father, guilt, problem-solving, self-reliance, support seeking, doctor, solution, possibility, among others (Figure 1). The content of this class represents the presence or absent of the adaptive coping strategies and their impact. The following extracts represent this context:

I am not going to share anything with my parents 'cause if I do so, they will take me out of dance school. I am not going to share anything with my dance colleagues because

I don't know what they are going to think of me. (S5)

"Can you realize that every time you put off seeing the doctor, the worse it gets ..." (S5);

"Fear of not being able to dance, fear of getting injured for good, fear of what may happen ..." (S5);

"Imagine you are going through this pain situation and little by little you're going to see yourself having a strong self-confidence, feeling that this pain does not belong to you" (S7).
Class 4 called "Pain Register" corresponded to $13.58 \%$ of TS. These are the main TS of this class: discuss, coping, fill in, mark, diary, take note, problem, forget, put, day, strategy, among others (Figure 1). The content of this class represents the process of filling the Pain Diary, as a way to register the pain. This helps them visualize what occurred before pain episodic, which coping strategy would be better, and the post-coping, that is the assessment on the functionality of such strategies in pain relief, working as a psycho-educative, self-control, and self-regulation material. The following extracts illustrate this context:

"This is a pain diary; it is like a regular diary. The idea is that everyday you are in pain, while we are having this intervention project, you should take notes" (S1);

"What I have realized is that a lot of people is in pain. If this brings you any kind of pain, yes, write it down. Remember I said it could be any kind of pain" (S5);

"Don't forget to take note every time you feel pain..." (S4). 
Class 2 named "Techniques to control the stress" was equivalent to $16.36 \%$ of TS. These are main elements related to this class: breathing, work, relaxation, focus, tired, imagine, sleep, among others (Figure 1). The content of this class shows tiredness and ways to control the stress, as breathing assistance, relaxation and imagination. The extracts that express this context are:

"I got talking so you could relax the parts of your bodies, but when you work along with the right breathing, it helps a lot to relax. Just the fact of relaxing sometimes already helps relieving pain" (S2);

"Could you see the difference today when we had a relaxation session from last week without it? Could you tell if it was easier? The tendency is to get easier" (S2);

"Go and find some distraction, so you don't focus on pain, it tends to diminish ..." (S5).

Class 3 entitled "Intervention Process" had $20.68 \%$ of TS. These are the main elements of this class: learn, assess, distraction, accommodation, start, questionnaire, among others (Figure 1). The content of this class depicts all the intervention process, from assessment to the adaptive coping strategies teachings, like $a c$ - commodation and distraction. The following extracts illustrate this context:

"Well, you know about the research process that I am doing and everything. We have the assessment part before so that I could just see how you were" (S1);

"I'm coming in the end of the year... I need to know for sure if I'm coming in November or December to make a final assessment with those questionnaires, all over again" (S8).

The dendogram and the analysis of this first corpus (Figure 1) show how much the mediator had been oriented to meet the intervention goals, highlighting the whole program proposed to change the coping with pain. From the psychological assessment, the mediator emphasized the register in the Pain Diary, the intervention itself, focusing on relaxation, imagination, psychoeducation, and also on the discussion to make people aware of the importance to present adaptive coping strategies instead of the maladaptive.

The second corpus made by IRAMUTEQ was about the dancers' verbal reports. The DHC analyzed $250 \mathrm{TS}$, keeping $73.20 \%$ and generating fiveclasses. The software divided the corpus of the mediator's words in two subcorpora (Figure 2).

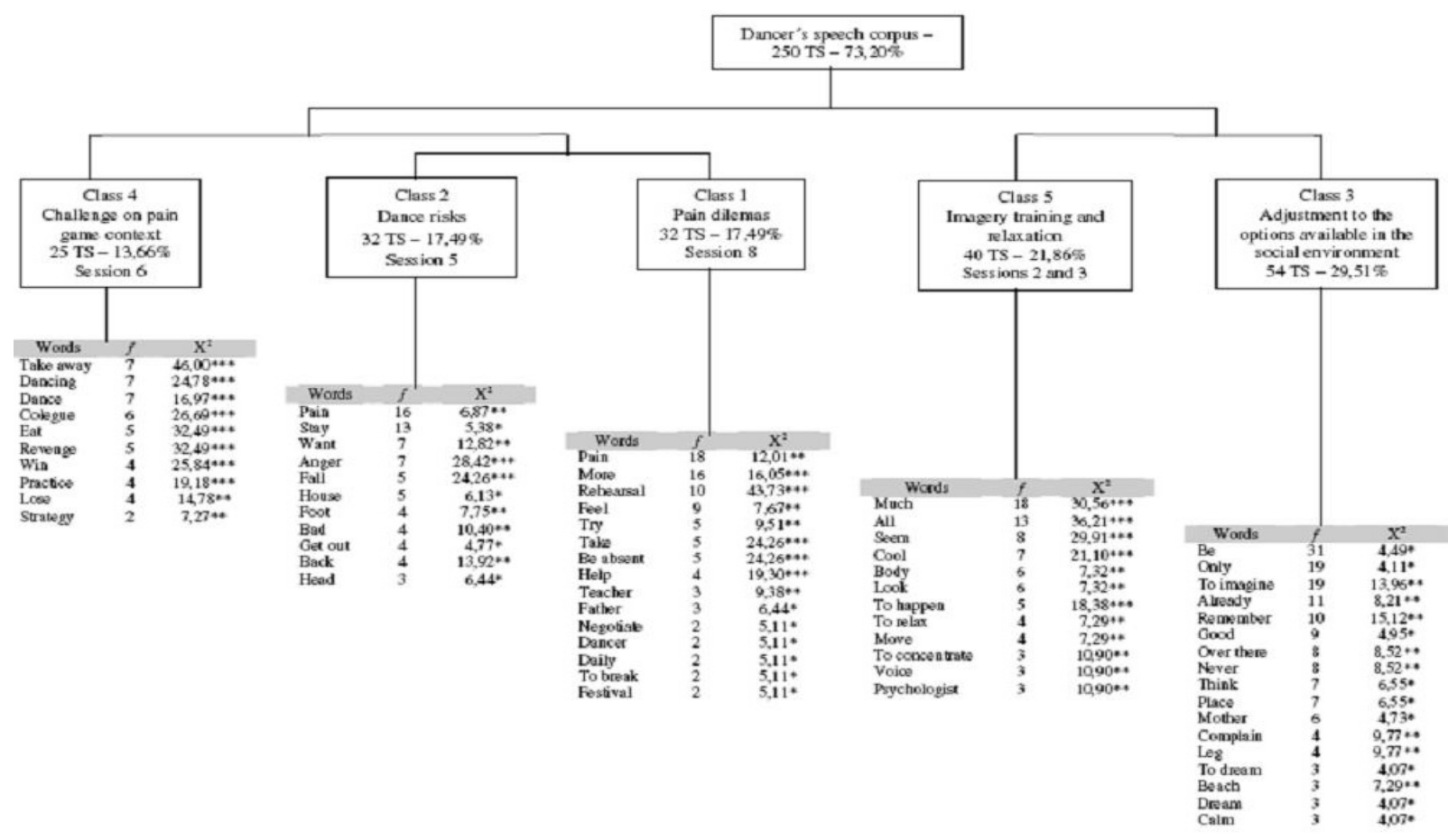

Figura 2. Dancers reports analysis during the intervention program in coping whith pain in dancers by Descending Hierarchical Classification.

Note: $* p<00,5 ; * p<00,1 ; * *<0,0001$, teste Qui-Quadrado, software IRAMUTEQ. 
The first subcorpus of the dancers' verbal reports was entitled "Stress Management", and it was composed by Class 3 and 4 . These classes present verbal reports about how the dancers deal with social and dance stressors, and about relaxation and use of imagination. "Stress management" is the Class 3, indicative of adjustment to the options available in the social environment, and the Class 5 is indicative of the imagination and relaxation practices. The second subcorpus called "Intervening on the Context of Pain". It was formed by Class 1, 2 and 4 . They have relations with the challenge to present the adaptive coping, which include the challenge in the context of the Pain Game, risks of dancing, and pain dilemmas.

Data were again reorganized in "Challenges to Use the Adaptive Coping", opposing the Class 4 -Challenges in the Context of the Pain Game - to Class 1 - Pain Dilemmas, and Class 2 - Dance Risks. Finally, there was a last division, called "Pain and Dance: Relations between Autonomy and Competence", with Class 1 - Pain Dilemmas and Class 2 - Dance Risks in opposition (Figure 2).

In the first partition, Class 3 named "Adjustment to the Available Options in the Social Environment", as part of "Stress Management" corpus, corresponded to $29.51 \%$ of TS. These are the main elements of this class: beach, complain, leg, remember, dream, calm, there, never, place, think, mother, imagine, alone, among others (Figure 2). The content of this class illustrates how much they could imagine themselves in other pleasing contexts, like the beach, to forget about pain, or even use breathing to help. Moreover, they need to adjust themselves to the fact that they do not have the necessary support at home, afraid of being taken out of the dance school by their mothers, preferring many times to be alone. It occurs the opposite with the mothers that were once ballet dancers, who comprehend the situation, what happened to 3 participants. The following extracts illustrate this context:

"I imagined myself going to the beach", "also to the beach", "beach", "beach" (S2);
"I heard you partly speaking, partly not, I just remember you talking about the mouth, after that I started to dream" (S4);

"We were there in Joinville, warming up, and E. Told us to breath deeply and relax, and then she got lifting some legs and more" (S2).

"I imagined myself getting home and asking my mom for help, I imagined I was crying, with a terrible pain, and she said she would take me out of the dance school" (S7).

Class 5 called "Imagery training and relaxation", as part of the "Stress Management" corpus, obtained $21.86 \%$ of TS. The main TS in this class were: focus, voice, psychologist, happen, seem, cool, relax, move, body, look, among others (Figure 2). The content of this class represents the association of relaxation in order to enhance the imagination practice, which requires focus, the voice tone used by the psychologist, and the whole process itself. The following extracts illustrate this context:

"I couldn't focus it right, but after sometime, it worked... as you were speaking I was getting completely relaxed" (S2);

"I didn't have much control and I could imagine the presentation pretty well, it was cool!" (S3);

"I was able to imagine what I couldn't; it was good, pretty cool, because I couldn't do it before" (S4);

"I think that here we relaxed, rested, I couldn't imagine myself with one kind of clothes, in going to the theater with other kind, I could imagine as though nothing had happened before, you know... I can't explain!"' (S2).

In opposition to those classes, the Class 4 named "Challenges in the context of the Pain Game", as part of "Intervening on the context of the pain" corpus, corresponded to $13.66 \%$ of TS. These are the main elements related to this class: eat, win, revenge, get away, practice, colleague, strategy, dance, dancing, among others. The content of this class pictures the more discussed subjects during the Pain Game, in the "challenges cards" (S6). It was possible to identify that there was a rigorous food control, which is considered a risk factor for the eating disorders, associated 
to weakness and pain: - "If you stop eating... no, if the person is feeling fat, they can get on a diet" (S6). There are verbal reports of getting away from colleagues to practice on their own, overloading the body and causing more pain:

"Getting away from something that has nothing to do, because, if you want to practice more, it is your own business, there is nothing to do with the group" (S6);

"In my opinion, there is nothing wrong there, in practicing on other times, if you want to get better" (S6).

We observed that they do not have the courage to take revenge on those that take their role on the choreography, in case of serious injury, but it makes them deeply upset -"I would not think of revenge because my dance colleagues are not colleagues, they are true friends" (S6). About getting injured the presentation and the need of a substitute: "I think I would be sad, because I wouldn't be able to dance, I would be a little angry" (S6). Besides, how badly they wanted to win the game, revealing high competitiveness, which allowed during the ludic moments of the Pain Game - "How can anybody else win?", "Why does she win all the time? I answered too!", "That's unfair! That's cheating!" - In this meantime the group colleagues would say: "Lose it, lose it, lose it!" (S6).

Class 1 called "Pain Dilemmas, as part of the "Intervening on the context of pain" corpus, was equivalent to $17.49 \%$ of TS. The main elements related to this class were: help, take, absence, rehearsal, negotiate, teacher, ballet dancer, diary, break, festival, father, try, feel, pain (Figure 2). Its content deals mainly with the difficulties to negotiate with the teacher for lighter rehearsal, for being in pain, the fear of being absent and fear of telling the parents about the pain, afraid of being taken out of the dance group, and not be able to participate in the festivals.

The following extracts illustrate this context:

"I have never been absent from the rehearsals, unless I break my feet and can't practice" (S6);

"I negotiate with my teacher to have lighter rehearsals. On this, $P$. would never agree... I don't even try" (S6);
"The solution was ask another person for help, in order not to feel pain anymore" (S7).

"Dance Risks" is the Class 2, as part of the "Intervening on the context of pain" corpus, and correspond to $17.49 \%$ of TS. These are its main words: fall, anger, back, badly, head, home, do, want, stay, pain, among others (Figure 2). The content of this class represents how much the dance has relations with the pain, and to the risk that they are of getting hurt and having to leave the group, which may cause anger and frustration. These feelings also occur because of some lack of understanding from friends and family who are not part of a dancing environment. The following extract illustrates this context: "I get angry when I feel a lot of pain and someone comes to annoy me, feel like hitting them ..." (S5).

When referring to a possible substitute, in case of an injury, they spoke:

"I think that if I saw her I wouldn't treat her badly, but within myself, in a moment of anger, it is a disappointment, I think that in a moment of anger, when I found out it was her" (S6).

"I'm think today everybody is in pain, I feel a lot of pain here and on my back" (S5).

About to helplessness of not finding any more solution for the pain, they said:

"Sometimes I feel that for the pain in my back, because I think that I'm going to cure it, but it is going to hurt again, so I think it's not worth it to mess with it" (S5);

"Even when you are in pain you will have to do it... sometimes there's nothing you can do" (S6).

The analysis of the dendogram and the second corpus (Figure 2) shows the relations between the dance and pain, and the threat that a possible injury imposes to the competence of the dancers. Moreover, there is also a threat to their needs of autonomy because dancers cannot share their pain with their parents, and have afraid that they could take them out from dance school, as well they cannot looking for a doctor with fear of stop dancing for an indefinite time. In other words, many times other people become responsible to their lives. Besides, friends who do not belong to the dance context do not comprehend 
the reason for so many rehearsals, not also why so much pain, affecting, in this way, their relationships. In this context, we realized that they presented more maladaptive coping strategies than adaptive ones. The psychological intervention, the imagery practice and the psycho-educative process gradually adapted and changed this pattern. The Pain Game was important for the dancers that the DHC analysis produced a specific class - the Class 4 (Figure 2). It shows us that it is possible to apply this game in more than one session, and how important is the use of a ludic psycho-educative resource, not only for kids but for teenagers too.

The last analysis jointed the verbal reports of the mediator and the participants in a single corpus, but each one of them remained as a separate topic (Figure 3). By DCH, the thematic corpus analyzed $667 \mathrm{TS}$, retaining $83.96 \%$ and generating four classes. The software split the thematic corpus in two subcorpora (Figure 3).

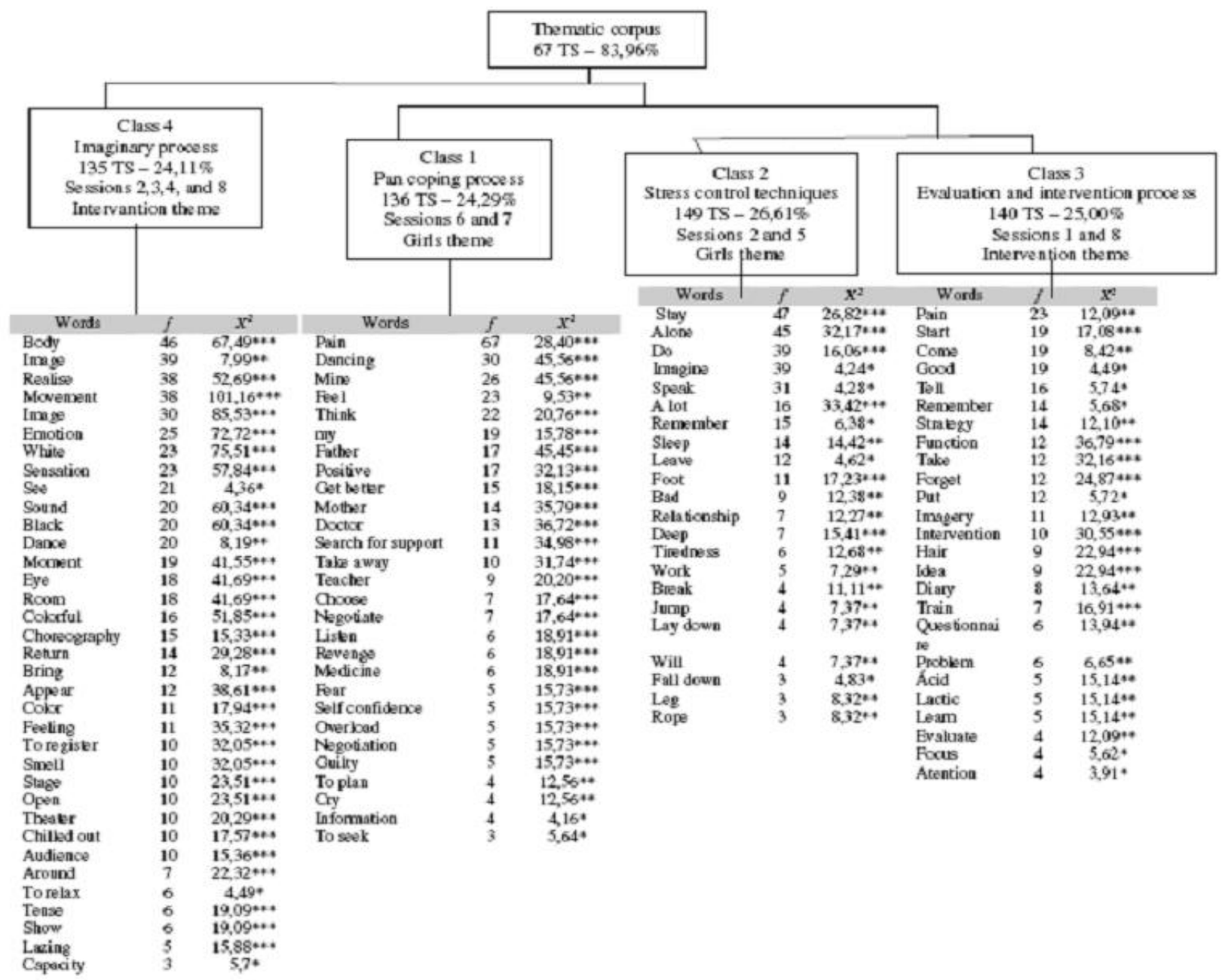

Figura 1. Mediator's report analysis during the intervention program when coping with pain in dancers by Descending Hierarchical Classification.

Note: ${ }^{*} \mathrm{p}<00,5 ; * *_{\mathrm{p}}<00,1 ; * * \mathrm{p}<0,0001$, Qui-Squared test, IRAMUTEQ software.

The first subcorpus called "Intervening on the Coping with Pain" contains the Class 4 "Imagery Process" that presents the imagination process. The second subcorpus is "Stress-Coping" formed by three classes: Class 1 - Process of coping with pain, Class 2 - "Control Stress
Techniques", and Class 3 - Process of assessment and intervention. These classes are related themselves by inclusion the processes of coping with pain, techniques to control of stress and the process of evaluation and intervention. Data were split once again into a new subcorpus, op- 
posing the Class 1 to the Class 2 and Class 3 (Figure 3).

In the first partition, Class 4 called "Imagery Process", as part the "Intervening on the Coping with Pain" corpus, was equivalent to $24.11 \%$ of TS. Its main elements were: movement, image, white, black, emotion, body, sensation, colorful, feeling, record, smell, stage, theater, tense, relaxed, show, color, choreography, audience, capacity, dance, among others (Figure 3). The content of this class represents the process used to imagine, which makes use of the sensory perception, involving all the senses, sight, smell, touch, hearing, taste, and the perception of sensations, emotion, and feelings, that appear when imagining a given situation. The following extracts illustrate this context:

"You realize that everyone around you has seen your mistake, what is the sensation of doing this wrong movement in front of everybody" (S8);

"Is the image colorful or black and white? What emotions come for participating of this festival and do things very well?" (S8);

Does it have any sound? Does it have any smell? What kind of emotion do you have standing on this stage? Does it bring out any feeling? Is it a good or bad sensation to be rehearsing on this stage? Are you alone or with other people? (S3)

Opposing to the Class 4, the Class 1 called "Process of Coping with Pain", as part of the "Stress-Coping" corpus, was equivalent to $24.29 \%$ of TS. The main elements related to this Class 1 were: dance, father, mother, doctor, search for support, positive, get away, pain, teacher, hear, revenge, medicine, get better, negotiate, fear, self-confidence, overload, guilt, plan, cry, feel, search, information, among others (Figure 3). The content of this class deals mainly with the possible coping strategies, positive and negative, the preliminary cognitive assessment, the influences the choice of certain strategies, and its impact. The following extracts illustrate this context:

If you got here crying because of pain, and a mother or father associate it with the dance, of course that sooner or later the threat will come, they will come and say you are out, so you have to negotiate. (S7)

Fear of not being able to dance, fear of getting seriously injured, fear of what may happen... I think about putting off the visit to doctor so I could keep on dancing... that feeling that if you see the doctor, he is going to tell you to stop dancing because that is the only option. (S5)

"You need to do something again what didn't work, and not say I give up, you can have self-confidence and think that everything is going to be ok one day, that everything is going to be all right" (S7),

In another partition, Class 2 called "Techniques to Control of Stress", as part the "StressCoping" corpus, was equivalent to $26.61 \%$ of TS. The main elements related to this class were: stand, can, deep, sleep, tired, bad, relaxation, break, stay, along, leg, jump, rope, lay, will, work, remember, fall, leave, speak, imagine, among others (Figure 3). The content of this class is about relaxation and imagination as techniques to control the stress, and to reduce the pain stressor present in the dancers' daily routine. The following extracts illustrate this context:

The pain got reduced; little by little and then it was gone. I did it! It seemed like I was in going away, you know, it is like it was fading, and it was changing its colors and shapes and felt like moving away from pain while you were saying that. (S5)

"Distraction is a good strategy, jumping the rope last week got you all excited and it's a great distraction strategy" (S7);

"When you work along with breathing it helps a lot to relax and the only fact of relaxing, sometimes, helps diminishing pain" (S2).

Opposing to that Class 2, the Class 3 named "Process of Assessment and Intervention", in "Stress-Coping" corpus, was equivalent to $25.00 \%$ of TS. These are the main elements: intervention, forget, hair, idea, start, practice, acid, lactic, learn, questionnaire, diary, imagination, strategy, assessment, problem, focus, attention, among others (Figure 3). The content of this class shows the psychophysiological 
measures of pain (blood and hair biochemical analysis; pain diary, questionnaires), just like the intervention process, which included relaxation, imagination, learning about coping strategies, with psycho-educational sessions. The following extracts illustrate this context:

"I liked the intervention very much, but no hair cutting" (S8);

"It's the imagination practice, let's start simple, and then make it harder, let's take one thing at a time" (S1).

The lactic acid is what I measured with punctured finger, that is to evaluate the lactic acid, which is a chemical substance that the body releases when you do a lot of exercise, and that thing in excess is what causes pain. (S5)

In the dendogram and the thematic analysis (Figure 3) we verify the pain assessment process. This process contains questionnaires, Pain Diary, psychophysiological measures, as well as the intervention process, which includes techniques to control the stress with relaxation, strategies to cope with pain. It also includes psycho-education to discriminate the adaptive and the maladaptive strategies; and imagery practice, besides the sensory process of this intervention. Moreover, we did the Similitude Analysis (Figure 4).

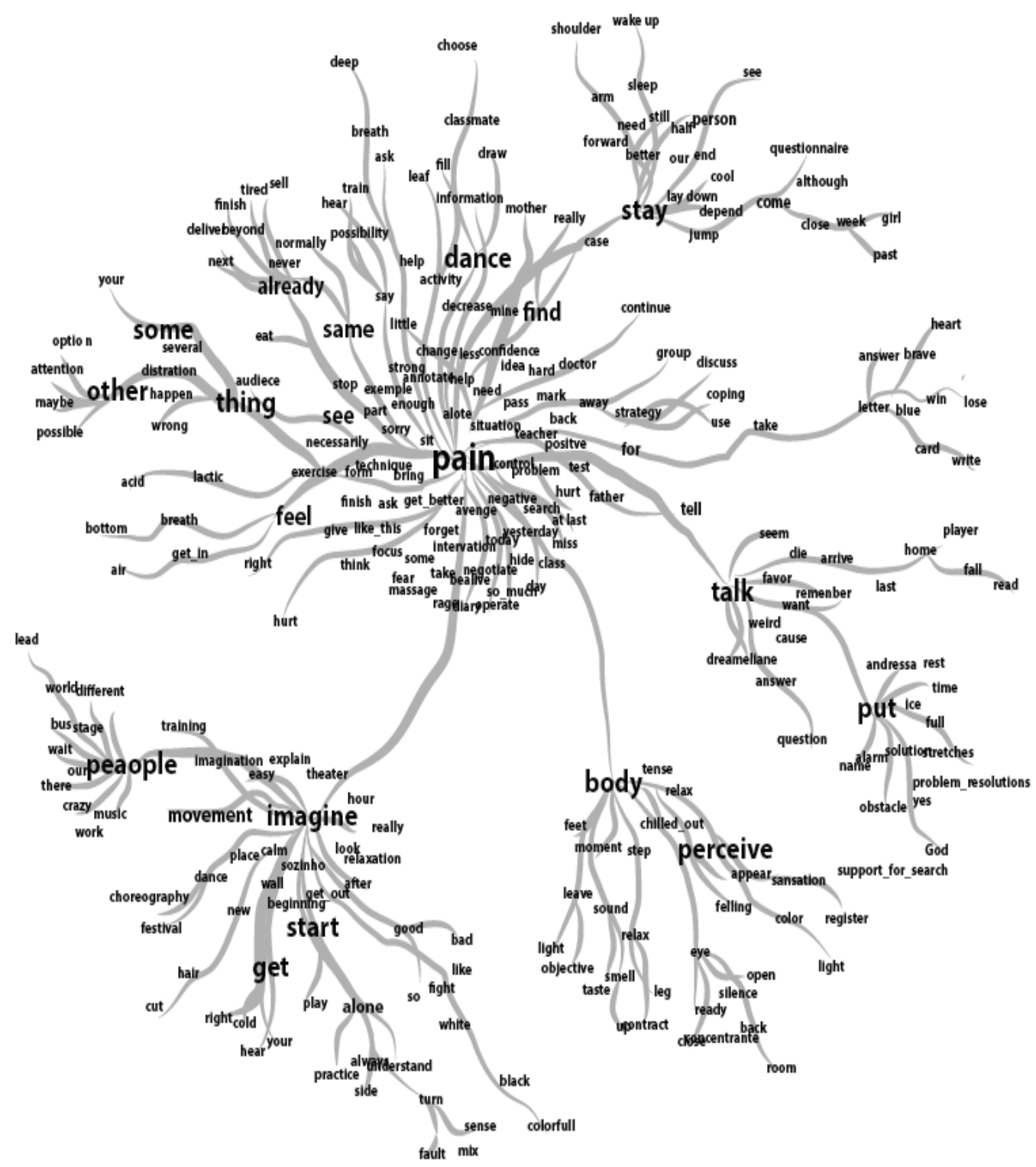

Figure 4. Analysis of similarity of thematic analysis of verbal reports of the dancers and the mediator during intervention program in coping with pain. 
In the Similitude Analysis, it is interesting to observe the words interconnection, as well as the level of relation between them, which rate of co-occurrences between them may be stronger or weaker (Chi-squared test). Thus, this last analysis showed the strong relation of pain, core word, with rehearsal, technique, control, and problem. This makes much sense, since the exercise, the technique, the rehearsals, and keeping control bring pain as a problem. On the same cluster are the feelings fear, anger, the verb feel, as well as strategy and self-confidence. This way, it is seen that pain bring out anger and fear in those dancers, feelings that need to be worked out so that there is no pain "catastrophization"; in this regard, it's possible to present the Selfreliance, one adaptive coping strategy.

The words teacher, forget, massage, and doctor are also close themselves (Figure 4). Considering that the dancers do not try to negotiate with their teacher for lighter practices, and do not looking for a doctor when they are in pain, because they feel threatened; this intensifies the sensation of pain, and psychologically the basic needs of autonomy and competence remain threatened. Mother and colleague are more distant words, just like audience, distraction, and attention. However, the word father is closer to the pain, It is worth having in mind that the IRAMUTEQ considers the combinations of words, therefore, in this case, it meant pais ("parents", plural of father in Portuguese), that is, the combination of mother and father is more connected to pain than only the mother or father only. There are strong evidences that connect the word pain with: stay, speak (therefore, relates to want, remember, problem-solving, $o b$ stacle, solution, stretch, and alarm clock), body, (this one related to perceive, sensation, feeling, relax), imagine (related to do, dance, choreography, festival, alone), and finally, feel (related to breathe deeply; Figure 4).

\section{Discussion}

This study has a methodological character, intending to show the possibilities of analysis of the content of a psychological intervention that aim to promote the coping with pain in ballet dancers, in order to analyze their verbal report and the psychologist's reports, who has the control of the process of mediation of learning. The verbal reports along the intervention were, then, analyzed by the software IRAMUTEQ (Camargo \& Justo, 2013, 2015).

By IRAMUTEQ it was possible to identify in the graphic representations of the mediator's verbal reports, a strong emphasis on pain in its relations with the rehearsals and the practices, the lactic acid, the dance, the relation with the body, as well as the self-perception, the sensations and emotions associated with the context. This content is present in some relevant national studies (Almeida \& Flores-Pereira, 2013; Meereis, Teixeira, Pranke, Lemos, \& Mota, 2013) and some of international importance (Cahalan et al., 2015; Jacobs, Hincapié, \& Cassidy, 2012; McEvan \& Young, 2011; Wyon \& Koutedakis, 2013), what reinforce the importance of this type of intervention proposal. Furthermore, the coping strategies have a strong connection with being able to imagine.

In the set of data from the dancers, we can highlight the words distract and negotiate, which were strongly associated with pain. The distraction strategy is very usual among people in this age (Skinner \& Zimmer-Gembeck, 2007). This behavior is classified in the coping family called Accommodation, being indicative of a perception of the stressor as a challenge and not as a threat to the basic need of Autonomy, according to the Motivational Theory of Coping (Skinner et al., 2003; Skinner \& Wellborn, 1994). However, the coping strategy named Negotiation, which belongs to the same coping family (Skinner et al., 2003), in the case of dancers, has a less adaptive function, because the dancers present difficulties to negotiate with their teacher.

The attempts to reduce the intensity or frequency of the exercises when you are in pain may result in leaving the dance group, and it is perceived as worse than being in pain. Taking into account, not only the dance context, but also the development period of these dancers are - the adolescence -, Compas et al. (2012) state that the "secondary control strategies", like 
distraction, are associated with a better adjustment of children and adolescents. In a context of pain at the hospital, Motta et al. (2015) identified distraction as an adaptive coping strategy in children and adolescents. Therefore, coping with pain by distraction could be promote in dancers, while negotiation should be better studied because in this context it presents a psychological function theoretically different from the MTC. In this same direction, data has shown a strong inverted relation between pain and doctor, the same occurring with the teacher. These people are not seeing therefore as a source of social support in this situation. The social support seeking is more frequent with the colleagues in pain situation, but is also related to sharing (or not sharing) the pain with mother or father, following the typical teenager pattern, when the social group has a great influence (Zimmer-Gembeck \& Skinner, 2011).

It was possible to characterize a pattern of related coping strategies - Self-reliance, Information Seeking, Accommodation and distraction - all of which related to the perception of the stressor as a challenge and to a more positive outcome in a long term (Skinner et al., 2003). However, these are not close to coping strategies targeting Problem-Solving, which include stretching and the Support Seeking. Then, selfreliance in excess and accommodation in relation to the stressor, by distraction, for example, may increase the health risk, considering pain as a warning sign. It is important to evaluate the adolescent's coping set in this context of health risk, because, according to Jacobs et al. (2012), the type of coping strategy presented by the dancers may influence the frequency and the intensity of pain/injury.

Indirectly dealing with pain, without confronting the stressor - excess of physical exercises - and not seeking the social support from adults (teachers and parents) build up a risk situation, which is perceived by the dancers, because the dance is associated with the word fear and pain features, imagined on Session 5 of the intervention. One can clearly see how much pain itself represents a threat to dancing competence and its autonomy, causing fear. Confirming that condition we have the association between the words speak and cry. It looks positive the fact that the intervention, which used the imagery technique, generate associations between imagine, rehearsal, plan, suggesting a more adaptive set of coping strategies in the medium or long time. According to the thematic analysis, the most highlighted words in the intervention were: pain, body, do, imagine, dance, feel, dancing, stay, speak, and realize. Thus, it is possible to verify a functional psychological logic for the Similitude Analysis, proving its feasibility and precision.

Methodologically, the IRAMUTEQ, commonly used to analyze interviews, and to verify the Social Representations, showed to be pertinent, reliable, and useful to analyze psychological group intervention. The idea of analyzing the verbal content of an interactive context reduces the researcher's time whose in the past needed to do the content analysis. It also decreases the mistakes caused by the researcher's subjectivity when they do the categorization. This way, precise categories are created, taking in account the frequency of the words they used, as well as in which context they appear, the relation level between them measured by Chi-squared test and significance level, and presenting graphics which easy visualization of the analyzed context.

Some limitations have to be considered. After the categorization in classes, it is the researcher's role to give a meaning to these new classes. Thus, the researcher needs to have a thorough knowledge of the theme in order to name the wider category, which includes all the components related to the set categories. Besides, building the corpus is a hard work, for the transcript content needs to become into corpus so to be analyzed. When there is a coding mistake in the command lines, the software does not process the analysis, it is up to the researcher to identify the mistake and correct it. Likewise, spelling mistakes are not interpreted by the software, just like colloquial words; again, it is up to the researcher to alter the speech so they become more scientific, but never altering meaning. It is worth mentioning that the software is a tool, a resource to help the researcher with his analysis. 
Single-handedly, this tool cannot understand, but only categorize the sentences from the codes. Then, reflecting on those codes, the researcher carries out the analysis itself.

Despite these characteristics, the software delivers accurate results, without subjective interference from the researcher. This software has been internationally used. This is one of the first researches that applied the software to analyze psychological interventions, then, it is highly recommended to carry out more researches, with different populations, in order to ensure that the method is stable when used in other studies. This precaution is important, especially due to a lack of psychological intervention programs in the country about coping, dancing or adolescents, in groups and, particularly, in pain contexts.

\section{References}

Alcântara, T. V., Shioga, J. E. M., Lima, M. J. V., Lage, A. M. V., \& Maia, A. H. N. (2013). Intervenções psicológicas na sala de espera: Estratégias no contexto da oncologia pediátrica. Revista da Sociedade Brasileira de Psicologia Hospitalar, 16(2), 103-119. Retrieved from pepsic.bvsalud.org/scielo.php?script $=$ sci_arttext\&p $\mathrm{id}=\mathrm{S} 1516-08582013000200008$

Almeida, D. D. D., \& Flores-Pereira, M. T. (2013). As corporalidades do trabalho bailarino: Entre a exigência extrema e o dançar com a alma. $R e-$ vista de Administração Contemporânea, 17(6), 720-738. Retrieved from http://www.anpad.org. $\mathrm{br} / \mathrm{rac}$

Andersen, M. B. (2011). Aspectos abrangentes da psicologia do esporte. In J. L. van Raalte, \& B. W. Brewer (Eds.), Psicologia do Esporte (2 $2^{\text {nd }}$ ed., T. B. Hildegard, Trans., pp. 13-23). São Paulo, SP: Santos.

Cahalan, R., O'Sullivan, P., Purtill, H., Bargary, N., Ni Bhriain, O., \& O'Sullivan, K. (2015). Inability to perform because of pain/injury in elite adult Irish dance: A prospective investigation of contributing factors. Scandinavian Journal of Medicine \& Science in Sports, online. doi:10.1111/ sms. 12492

Camargo, B. V., \& Justo, A. M. (2013). IRAMUTEQ: Um software gratuito para análise de dados textuais. Temas em Psicologia, 21(2), 513-518. doi:10.9788/TP2013.2-16
Camargo, B. V., \& Justo, A. M. (2015). Tutorial para uso do software IRAMUTEQ. Retrieved from http://www.laccos.com.br/index. php?option $=$ com_content\&view $=$ article \&id $=2$ 08\%3Atutorial-do-software-iramuteq-em-portu gues\&catid $=40 \% 3$ Aoutros\&Itemid $=9 \&$ lang $=\mathrm{br}$

Caudill, M. A. (1998). Controle a dor antes que ela assuma o controle: Um programa clinicamente comprovado (D. M. Bolagnol, Trans.). São Paulo, SP: Summus.

Chaves, C., Vásquez, F., \& Hervás, G. (2015). Positive interventions in seriously-ill children: Effects on well-being alter granting a wish. Journal of Health Psychology, 29(1). doi:10.1177/1359105314567768

Compas, B. E., Jaser, S. S., Dunn, M. J., \& Rodriguez, E. M. (2012). Coping with chronic illness in childhood and adolescence. Annual Review of Clinical Psychology, 8, 455-480. doi:10.1146/ annurev-clinpsy-032511-143108

Encarnación, M. L. G., Meyers, M. C., Ryan, N. D., $\&$ Pease, D. G. (2000). Pain coping styles of ballet performers. Journal of Sport Behavior, 23(1), 20-32. Retrieved from https://www.thefreelibrary.com/Pain+Coping+Styles + of + Ballet + Perf ormers.-a061909294

Godtsfriedt, J., Andrade, A., \& Vasconcellos, D. I. C. (2014). Treinamento mental no tênis: Revisão sistemática da literatura. Revista Brasileira de Ciências do Esporte, 36(2), 577-586. doi:10.1590/S0101-32892014000200020

Gould, D., Damarjian, N., \& Greenleaf, C. (2011). Treinamento imaginário para a maximização do desempenho. In J. L. Raalte \& B. W. Brewer (Eds.), Psicologia do Esporte (2 ${ }^{\text {nd }}$ ed., T. B. Hildegard, Trans., pp. 49-74). São Paulo, SP: Santos.

Guarino,L. (2015). Is dancea sport? A twenty-first-century debate. Journal of Dance Education, 15(2), 77-80. doi:10.1080/15290824.2015.978334

Heaney, C. A., Walker, N. C., Green, A. J. K., \& Rostron, C. L. (2015). Sport psychology education for sport injury rehabilitation professionals: A systematic review. Physical Therapy in Sport, 16(1), 72-79. doi:10.1016/j.ptsp.2014.04.001

Jacobs, C. L., Hincapié, C. A., \& Cassidy, J. D. (2012). Musculoskeletal injuries and pain in dancers: A systematic review update. Journal of Dance Medicine \& Science, 16(2), 74-84. doi:10.1016/j.apmr.2008.02.020 
Karademas, E. C., Benyamini, Y., \& Johnston, M. (2016). Introduction. In Y. Benyamini, M. Johnston, \& E. C. Karademas (Eds.), Assessment in Health Psychology (pp. 3-16). Gottingen, Germany: Hogrefe.

Larsen, C. H., \& Henriksen, K. (2015). Psyhological momentum in team sport: An intervention program in professional soccer. Sport Science Review, 24(1-2), 27-39. doi:10.1515/ssr-20150007

Leandro-França, C., Murta, S. G., \& Villa, M. B. (2014). Efeitos de uma intervenção breve no planejamento para a aposentadoria. Revista Psicologia, Organizações e Trabalho, 14(3), 257-270. Retrieved from pepsic. bvsalud.org/scielo.php?script=sci_arttext\&pid $=$ S1984-66572014000300002

Lino, R. L., \& Ziliotto, D. M. (2013). Possibilidades da psicologia do trabalho nas organizações: Relato de experiência em indústria calçadista. Revista Psicologia em Foco, 5(5), 5-21. Retrieved from pepsic.bvsalud.org/scielo.php?script $=$ sci arttext\&pid=S1808-42812010000200008

Lipp, M. E. N. (2012). Bases teóricas da Psicoterapia Cognitivo-Comportamental. In M. E. N. Lipp \& E. M. P. Yoshida (Ed.), Psicoterapias breves nos diferentes estágios evolutivos (Chapter 1). São Paulo, SP: Casa do Psicólogo.

Lopes, J., \& Almeida, L. S. (2015). Questões e modelos de avaliação e intervenção em Psicologia Escolar: O caso da Europa e América do Norte. Estudos de Psicologia (Campinas), 32(1), $75-$ 85. doi:10.1590/0103-166X2015000100007

Markland, D., Hall, C. R., Duncan, L. R., \& Simatovic, J. (2015). The effects of an imagery intervention on implicit and explicit exercise attitudes. Psychology of Sport and Exercise, 17(1), 24-31. doi:10.1016/j.psychsport.2014.11.007

Martens, R. (1987). Coaches guide to Sport Psychology. Champaign, IL: Human Kinectics.

McEven, K., \& Young, K. (2011). Ballet and pain: Reflections on risk-dance culture. Qualitative Research in Sport, Exercise and Health, 3(2), 152-173. doi:10.1080/2159676X.2011.572181

Meereis, E. C. W., Teixeira, C. S., Pranke, G. I., Lemos, L. F. C., \& Mota, C. B. (2013). Sintomatologia dolorosa em bailarinos: Uma revisão. Revista Brasileira de Ciência e Movimento, 21(2), 143-150. doi:10.18511/0103-1716/rbcm. v21n2p143-150
Motta, A. B., \& Enumo, S. R. F. (2010). Intervenção psicológica lúdica para o enfrentamento da hospitalização para crianças com câncer. Psicologia: Teoria e Pesquisa, 26(3), 445-454. doi:10.1590/S0102-37722010000300007

Motta, A. B., Perosa, G. B., Barros, L., Silveira, K. A., Lima, A. S. S., Garnier, L. E., ...Caprini, F. R. (2015). Comportamentos de coping no contexto da hospitalização infantil. Estudos de Psicologia (Campinas), 32(2), 331-341. doi:10.1590/0103166X2015000200016

Pfeifer, P. M., \& Ruschel, P. P. (2013). Preparo psicológico: A influência na utilização de estratégias de enfrentamento pós-transplante cardíaco. Revista da Sociedade Brasileira de Psicologia Hospitalar, 16(2), 153-165. Retrieved from pepsic.bvsalud.org/scielo.php?script=sci_arttext\&p $\mathrm{id}=\mathrm{S} 1516-08582013000200011$

Ramos, F. P. (2012). Uma proposta de análise do coping no contexto de grupo de mães e bebês prematuros e com baixo peso na Unidade de Terapia Intensiva Neonatal (Unpublished doctoral dissertation, Programa de Pós-Graduação em Psicologia, Universidade Federal do Espírito Santo, Vitória, ES, Brazil).

Ramos, F. P., Enumo, S. R. F., \& Paula, K. M. P. (2015). Teoria Motivacional do Coping: Uma proposta desenvolvimentista de análise do enfrentamento do estresse. Estudos de Psicologia (Campinas), 32(2), 269-279. doi:10.1590/0103166X2015000200011

Retinaud, P., \& Marchand, P. (2012). Application de la méthode ALCESTE aux $<<$ gros $>>$ corpus et stabilité des $<<$ mondes lexicaus $>>$ : analyse du $<<$ CableGate $>>$ avec IRAMUTEQ. In Actes des 11eme Journées internationales d'Analyse statistique des Données Textuelles (pp. 835-844). Liège, Belgique.

Singh, S. (2011). The meaning of pain during the process of embodiment: A case study of trainee modern dancer's experiences of pain. Sport, Education \& Society, 16(4), 451-465. doi:10.10 $80 / 13573322.2011 .589643$

Skinner, E. A., Edge, K., Altman, J., \& Sherwood, H. (2003). Searching for the structure of coping: A review and critique of category systems for classifying ways of coping. Psychological Bulletin, 129(2), 216-269. doi:10.1037/00332909.129.2.216 
Skinner, E. A., \& Welborn, J. G. (1994). Coping during childhood and adolescence: A motivacional perspective. In D. L. Featherman, R. M. Lerner, \& R. M. M. Perlmutter (Eds.). Life-Span Development and Behavior (pp. 91-133). Hillsdale, NJ: Lawrence Erlbaum Associates.

Skinner, E. A., \& Zimmer-Gembeck, M. J. (2007). The development of coping. Annual Review of Psychology, 58(1), 119-144. doi:10.1146/annurev.psych.58.110405.085705

Souza, M. P. R., Ramos, C. J. M., Lima, C. P., Barbosa, D. R., Calado, V. A., \& Yamamoto, K. (2014). Atuação do psicólogo na educação: Análise de publicações científicas brasileiras. Psicologia da Educação, 38(1), 123-138. Retrieved from pepsic.bvsalud.org/scielo. php?script $=$ sci_arttext\&pid $=\mathrm{S} 1414$

Stefanello, J. M. F. (2007). Treinamento de competências psicológicas: Em busca da excelência esportiva. Barueri, SP: Manole.

Vealey, R. S. (1991). Entrenamiento en imaginación para el perfeccionamiento de la ejecución. In J. M. Williams (Eds.). Psicología aplicada al deporte (pp. 308-344). Biblioteca Nueva.

Vieira, L. F., Vieira, J. L. L., \& Nascimento, J. R. A., Jr. (2013). O estado da arte da pesquisa em Psicologia do Esporte no Brasil. Revista de Psicologia del Deporte, 22(2), 501-507. Retreived from www.redalyc.org/pdf/2351/235128058020.pdf
Weinberg, R., \& Gould, D. (2014). Foundations of Sport and Exercise Psychology ( $6^{\text {th }} \mathrm{ed}$.). Champaign, IL: Human Kinectics.

Wright, J. H., Sudack, D. M., Turkington, D., \& Thase, M. C. (2012). Terapia Cognitivo-Comportamental de alto rendimento para sessões breves (G. W. Linck \& M. G. Armando, Trans.). Porto Alegre, RS: Artmed.

Wyon, M. A., \& Koutedakis, Y. (2013). Muscular fatigue: Considerations for dance. Journal of Dance Medicine \& Science, 17(2), 63-69. doi:10.12678/1089-313X.17.2.63

Zimmer-Gembeck, M. J., \& Skinner, E. A. (2011). The development of coping across childhood and adolescence: An integrative review and critique of research. International Journal of Behavioral Development, 35 (1), 1-17. doi:10.1177/0165025410384923
Recebido: 04/01/2016

$1^{a}$ revisão: $22 / 03 / 2016$ Aceite final: 03/04/2016 